\title{
Methylobacter tundripaludum sp. nov., a methane- oxidizing bacterium from Arctic wetland soil on the Svalbard islands, Norway $\left(78^{\circ} \mathrm{N}\right)$
}

\author{
Ingvild Wartiainen, ${ }^{1}$ Anne Grethe Hestnes, ${ }^{1}$ lan R. McDonald ${ }^{2}$ \\ and Mette M. Svenning ${ }^{1}$ \\ ${ }^{1}$ Department of Biology, Faculty of Science, University of Troms $\emptyset$, N-9037 Troms $\emptyset$, Norway \\ ${ }^{2}$ Department of Biological Sciences, University of Waikato, Private Bag 3105, Hamilton, \\ New Zealand
}

Correspondence

Mette M. Svenning

Mette.Svenning@ib.uit.no

\begin{abstract}
A Gram-negative, rod-shaped, non-motile, non-spore forming bacterium (SV96 ${ }^{\top}$ ) was isolated from wetland soil near $\mathrm{Ny}$-Ålesund, Svalbard. On the basis of 16S rRNA gene sequence similarity, strain SV96 ${ }^{\top}$ was shown to belong to the Gammaproteobacteria, related to Methylobacter psychrophilus Z-0021 ${ }^{\top}$ (99.1\%), Methylobacter luteus ATCC $49878^{\top}$ (97.3\%), Methylobacter marinus $\mathrm{A}_{4} 5^{\top}(97 \cdot 0 \%)$ and Methylobacter whittenburyi ATCC $51738^{\top}$ (95.8\%); the closest related species within the genus Methylomicrobium with a validly published name was Methylomicrobium album ATCC $33003^{\top}(95 \cdot 0 \%)$. Chemotaxonomic data (including the major fatty acids: $16: 1 \omega 8,16: 1 \omega 7$ and $16: 1 \omega 5 t)$ supported the affiliation of strain $S V 96^{\top}$ to the genus Methylobacter. The results of DNA-DNA hybridization, physiological and biochemical tests allowed genotypic and phenotypic differentiation of strain $\mathrm{SV} 6^{\top}$ from the four Methylobacter species mentioned above. Strain SV96 ${ }^{\top}$ therefore represents a novel species, for which the name Methylobacter tundripaludum sp. nov. is proposed (type strain $\mathrm{SV} 6^{\top}=\mathrm{DSM} 17260^{\top}=$ ATCC BAA-1195' $)$.
\end{abstract}

The genus Methylobacter was formed following the emendation of the description of the genus Methylococcus (Bowman et al., 1993), and Methylobacter species are equivalent to the similarly named group first coined by Whittenbury et al. (1970). The genus was further revised when three members of the genus Methylobacter were renamed as a new taxon Methylomicrobium (Bowman et al., 1995). At present the genus comprises the four species Methylobacter luteus (Bowman et al., 1993; Romanovskaya et al., 1978), Methylobacter whittenburyi (Bowman et al., 1993; Romanovskaya et al., 1978; Whittenbury et al., 1970), Methylobacter marinus (Bowman et al., 1993; Lidstrom, 1988) and Methylobacter psychrophilus (Omelchenko et al., 1996; Tourova et al., 1999).

Strain SV96 $^{\mathrm{T}}$ was isolated from a soil core collected from a wetland near the settlement Ny-Ålesund ( $78^{\circ} 56^{\prime} \mathrm{N} 11^{\circ} 53^{\prime}$ E), Svalbard, in July 1996. The soil emitted methane (Høj

Published online ahead of print on 26 August 2005 as DOI 10.1099/ ijs.0.63728-0.

Abbreviations: PLFA, phospholipid fatty acid; RuMP, ribulose monophosphate; sMMO, soluble methane monooxygenase.

The GenBank/EMBL/DDBJ accession numbers for the 16S rRNA gene, $p m o A$ and nifH sequences of Methylobacter tundripaludum SV96 ${ }^{\top}$ are AJ414655, AJ414658 and AY937260, respectively. et al., 2005) and had a $\mathrm{pH}$ of $6 \cdot 4$. The temperature of the soil was $10{ }^{\circ} \mathrm{C}$ at the surface and $5{ }^{\circ} \mathrm{C}$ at $10 \mathrm{~cm}$ below the surface; the permafrost level was at $25 \mathrm{~cm}$. After the fresh vegetation layer was removed, the upper $10 \mathrm{~cm}$ of the soil core was mixed, $2 \mathrm{~g}$ soil was taken and added to $10 \mathrm{ml}$ nitrate mineral salt medium (NMS) (Whittenbury et al., 1970) at pH 6•8, and shaken for $10 \mathrm{~min}$ at 200 r.p.m. After $10 \mathrm{~min}$ of sedimentation, $1 \mathrm{ml}$ supernatant was mixed with $9 \mathrm{ml} \mathrm{NMS}$ in a $120 \mathrm{ml}$ serum bottle (Alltech). The bottle was sealed with a rubber stopper and crimp cap. Twenty millilitres of air was replaced with $20 \mathrm{ml} \mathrm{CH} / \mathrm{CO}_{2}$ (95:5) mixture (both gases were $99.95 \%$ purity). The bottle was incubated at $20{ }^{\circ} \mathrm{C}$ and subcultured every $2-3$ weeks ( $1 \mathrm{ml}$ culture to $9 \mathrm{ml}$ fresh NMS medium). After four or five subculturing steps in liquid media, bacteria were plated on NMS medium containing $1.5 \%$ noble agar (bacteriological agar type E; Biokar diagnostics). The plates were incubated at $20^{\circ} \mathrm{C}$ in sealed chambers containing approximately $35 \%$ methane in air. Colonies were picked and restreaked. Heterotrophic contamination was checked by streaking colonies on agar plates with rich medium containing $0.5 \%$ tryptone, $0.25 \%$ yeast extract, $0 \cdot 1 \%$ glucose and $2 \cdot 0 \%$ agar. These plates were incubated at room temperature without additional methane. The cultures were considered to be pure when only one cell type was observed under light microscopy and no growth on nutrient rich medium was observed. Exospore 
formation was assayed by determining cell viability after heating 3-week-old cultures to $80^{\circ} \mathrm{C}$ for $20 \mathrm{~min}$ and then observing microcolony formation on NMS agar after 2 weeks incubation with methane (Bowman et al., 1993). Cyst formation was assayed by the method of Vela \& Wyss (1964). Tolerance to $\mathrm{NaCl}$ concentrations ranging from 0.01 to $1 \cdot 0 \%(\mathrm{w} / \mathrm{v})$ was determined with NMS agar cultures. Growth at $\mathrm{pH}$ values ranging from $5 \cdot 5$ to $9 \cdot 0(\mathrm{pH}$ was adjusted with $\mathrm{NaOH}$ or $\mathrm{HCl}$ ) and methanol concentrations ranging from $0 \cdot 1$ to $1 \cdot 0 \%(\mathrm{v} / \mathrm{v})$ was determined in liquid cultures of NMS.

The growth of $\mathrm{SV} 96^{\mathrm{T}}$ was measured at temperatures ranging from $5 \cdot 0$ to $40 \cdot 0^{\circ} \mathrm{C}$, using a temperature gradient apparatus with the opportunity to grow bacteria simultaneously at 10 different chosen temperatures. The temperature gradient was achieved using a metal cylinder with a flat top $(14 \mathrm{~cm}$ in diameter and $50 \mathrm{~cm}$ in length), where one end was attached to a cooling water bath and the other to a thermostatregulated heat block. The top of the cylinder had 10 holes, $5 \mathrm{~cm}$ apart in two parallel rows, which fitted a $27 \mathrm{ml}$ serum bottle (Alltech). The temperatures were measured at every second hole, where a small hole was drilled between the two parallel rows. To achieve temperatures from 5 to $40{ }^{\circ} \mathrm{C}$, two different experiments with partly overlapping temperatures were run. The temperature was first set from 5 to $12^{\circ} \mathrm{C}$ (a gradient of $0 \cdot 14^{\circ} \mathrm{C} \mathrm{cm}^{-1}$ ) and then from 11 to $40^{\circ} \mathrm{C}$ (a gradient of $0.58^{\circ} \mathrm{C} \mathrm{cm}^{-1}$ ). Cultures of $\mathrm{SV} 96^{\mathrm{T}}$ were prepared by adding $5 \mathrm{ml}$ starting culture to $27 \mathrm{ml}$ serum bottles. The bottles were sealed with rubber stoppers and crimp caps before $5 \mathrm{ml}$ air was replaced with $5 \mathrm{ml} \mathrm{CH} / \mathrm{CO}_{2}$ (95:5) mixture and the cultures were grown for 5 days. The $\mathrm{OD}_{600}$ was measured for the starting and 5-day-old cultures using a Spectramax 250 microplate spectrophotometer system (Molecular Devices). The maximum $\mathrm{OD}_{600}$ of $\mathrm{SV} 6^{\mathrm{T}}$ was $0 \cdot 72$, and was measured after 15 days at $20^{\circ} \mathrm{C}$. The experiment was repeated in three replicates at each temperature setting and the net growth calculated by subtracting the $\mathrm{OD}_{600}$ of the starting culture from the $\mathrm{OD}_{600}$ values of the 5-day-old cultures. Mean values for net growth and standard deviations were calculated.

The 16S rRNA gene was analysed as described previously (Lane, 1991). Phylogenetic analysis was performed using the software packages PHYLIP (Felsenstein, 1993) and TREEVIEW (Page, 1996) after multiple alignment of data by CLUSTAL_X (Thompson et al., 1997). Distances (Kimura two-parameter model) and clustering by neighbour-joining methods were determined by using bootstrap values based on 100 replicates (Fig. 1). The $16 \mathrm{~S}$ rRNA gene sequence of strain $S V 96^{\mathrm{T}}$ was a continuous stretch of $1487 \mathrm{bp}$. Sequence similarity calculations indicated that the closest relatives of strain SV96 ${ }^{\mathrm{T}}$ were Methylobacter psychrophilus Z-0021 ${ }^{\mathrm{T}}(99 \cdot 1 \%)$, Methylobacter luteus ATCC $49878^{\mathrm{T}}(97 \cdot 3 \%)$, Methylobacter marinus $\mathrm{A}_{4} 5^{\mathrm{T}}(97 \cdot 0 \%)$ and Methylobacter whittenburyi ATCC $51738^{\mathrm{T}}(95 \cdot 8 \%)$. Lower sequence similarities were found with all species with validly published names of the genus Methylomicrobium: Methylomicrobium album ATCC

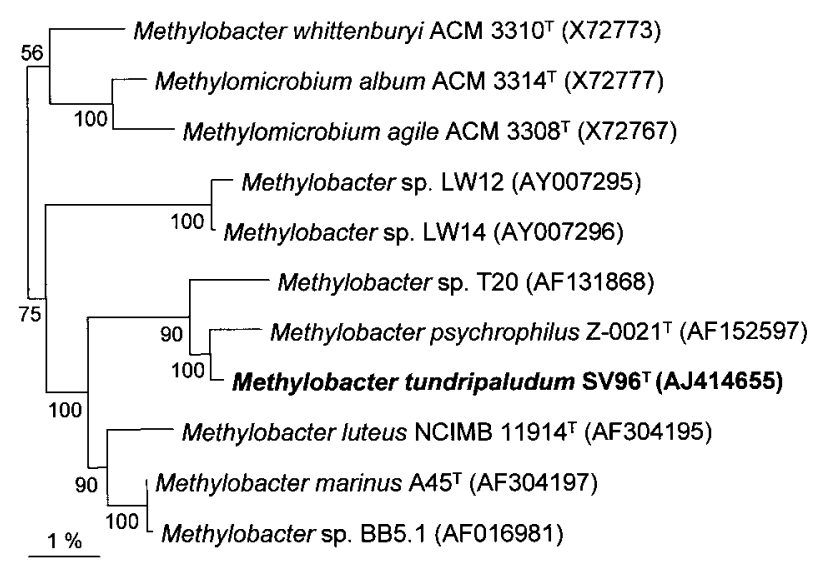

Fig. 1. Phylogenetic relationship of the 16S rRNA gene sequences of Methylobacter tundripaludum $\mathrm{SV} 6^{\top}$ and other strains of Methylobacter and related genera. The dendrogram shows the results of a neighbour-joining analysis in which DNADIST was used. Bootstrap values greater than $50 \%$ derived from 100 replicates are also shown. The bar represents $1 \%$ sequence divergence, as determined by measuring the lengths of the horizontal lines connecting any two species.

$33003^{\mathrm{T}}(95 \cdot 1 \%)$, Methylomicrobium agile ATCC $35068^{\mathrm{T}}$ $(94.5 \%)$ and Methylomicrobium pelagicum NCIMB $2265^{\mathrm{T}}$ $(94.0 \%)$. The pmoA gene was analysed as described previously (McDonald \& Murrell, 1997). Phylogenetic analysis and alignment of data were performed using the software package ARB (Ludwig et al., 2004) (Fig. 2). The nifH gene was amplified and sequenced as described previously (Poly et al., 2001). Sequence similarity searches in GenBank indicated that the closest related nifH sequence was derived from an uncultured $\mathrm{N}_{2}$-fixing bacteria (AY196439) (92\%); the

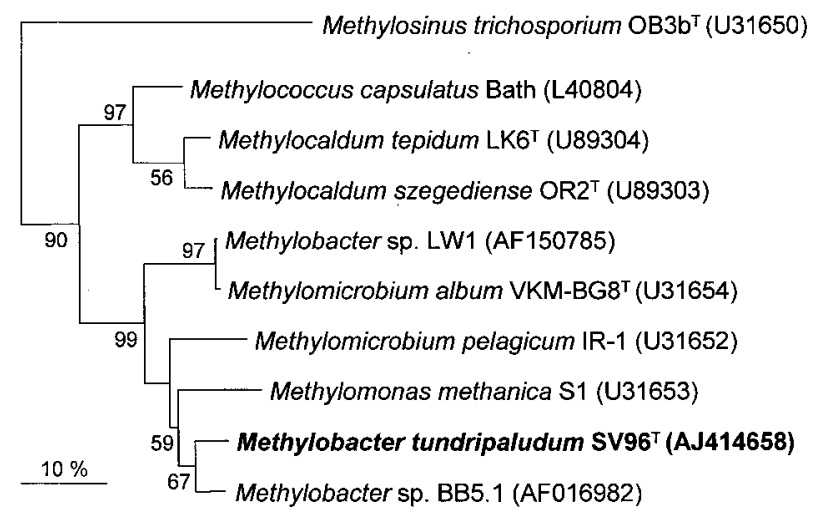

Fig. 2. Phylogenetic relationship of the deduced PmoA sequences of Methylobacter tundripaludum SV $96^{\top}$ and other strains of Methylobacter and related genera. The dendrogram shows the results of an analysis in which PROTDIST was used. Bootstrap values greater than $50 \%$ derived from 100 replicates are also shown. The bar represents $10 \%$ sequence divergence, as outlined in Fig. 1. 
closest matches with cultured bacteria were Methylobacter marinus $\mathrm{A}_{4} 5^{\mathrm{T}}(84 \%)$ and Methylobacter luteus NCIMB $11914^{\mathrm{T}}\left(=\right.$ ATCC $\left.49878^{\mathrm{T}}\right)(84 \%)$. The DNA base composition was determined by thermal denaturation using a Cary $4 \mathrm{E}$ Varian spectrophotometer at a heating rate of $0 \cdot 5^{\circ} \mathrm{C} \mathrm{min}^{-1}$. The $\mathrm{G}+\mathrm{C}$ content $(\mathrm{mol} \%)$ of the DNA was calculated by the equation of Mandel et al. (1970). DNADNA hybridization was performed with Methylobacter luteus ATCC $49878^{\mathrm{T}}$ according to the method described by Ezaki et al. (1989). It was not performed with Methylobacter psychrophilus $\mathrm{Z}-0021^{\mathrm{T}}$ or Methylobacter marinus $\mathrm{A} 45^{\mathrm{T}}$ because they were, to our knowledge, both unavailable from any culture collection.

The most closely related bacterium, Methylobacter psychrophilus Z-0021 ${ }^{\mathrm{T}}$ (Tourova et al., 1999), sharing 99.1\% 16S rRNA gene similarity, was isolated from a moss-vegetated area on the tundra in the polar Ural (Omelchenko et al., 1993). Despite the high 16S rRNA gene sequence similarity and the similar origin, the bacterial strains were different in several important morphological traits (Table 1). SV96 ${ }^{\mathrm{T}}$ was non-motile, $0 \cdot 8-1 \cdot 3 \mu \mathrm{m}$ wide and $1 \cdot 9-2 \cdot 5 \mu \mathrm{m}$ in length. Cells often appeared in pairs or in long chains. Colonies were pale-pink pigmented, but lost the pigmentation upon methane starvation. Cells of Methylobacter psychrophilus $\mathrm{Z}-0021^{\mathrm{T}}$ were reported to be cocci or diplococci, $1 \cdot 0-1 \cdot 7 \mu \mathrm{m}$ in diameter, and colonies were opaque cream (Omelchenko et al., 1996). The cells of SV96 ${ }^{\mathrm{T}}$ lysed in $2 \%$ SDS. The strain did not grow when $\mathrm{NaCl}$ was added to solid NMS medium and poor to no growth was observed with methanol as a carbon source. $\mathrm{SV} 96^{\mathrm{T}}$ grew at all $\mathrm{pH}$ values tested except for $\mathrm{pH} 9 \cdot 0$ and no exospores or cysts were revealed using the described methods. A type I membrane structure, with bundles of disc-shaped membranes, was confirmed using transmission electron microscopy (Fig. 3). The major phospholipid fatty acids (PLFAs) for $\mathrm{SV} 6^{\mathrm{T}}$ were $16: 1 \omega 8(34 \cdot 9 \%), 16: 1 \omega 7(23 \cdot 4 \%)$ and $16: 1 \omega 5 t(26 \cdot 3 \%)$. Isolate $\mathrm{SV}^{\mathrm{T}}{ }^{\mathrm{T}}$ had a $\mathrm{G}+\mathrm{C}$ content of $47 \mathrm{~mol} \%$ ( $\pm 1 \mathrm{~mol} \%)$, while Methylobacter psychrophilus $\mathrm{Z}-0021^{\mathrm{T}}$ had a G $+\mathrm{C}$ content of $45 \cdot 6 \mathrm{~mol} \%$ (Omelchenko et al., 1996). SV96 ${ }^{\mathrm{T}}$ was positive for the nifH gene by PCR (Poly et al., 2001). It was negative for the $m m o X$ gene in PCR assays (Fuse et al., 1998; Miguez et al., 1997) and no soluble methane monooxygenase (sMMO) was detected by colorimetric assay performed as described by Brusseau et al. (1990), with the modifications of Graham et al. (1992). SV $96^{\mathrm{T}}$ had an optimum growth temperature of $23^{\circ} \mathrm{C}$, but grew well at temperatures from 10 to $27^{\circ} \mathrm{C}$ (Fig. 4) and was clearly not psychrophilic. Methylobacter psychrophilus Z$0021^{\mathrm{T}}$ was reported to have a growth optimum between $3 \cdot 5$ and $10^{\circ} \mathrm{C}$ with no growth at temperatures above $20^{\circ} \mathrm{C}$ (Omelchenko et al., 1996). To confirm that $S V 96^{\mathrm{T}}$ and Methylobacter psychrophilus Z-0021 ${ }^{\mathrm{T}}$ represent different species, a DNA-DNA hybridization should be performed; however, Methylobacter psychrophilus Z-0021 ${ }^{\mathrm{T}}$ is not available from any culture collection (P. Kämpfer, personal communication). This is also the situation for Methylobacter marinus $\mathrm{A} 45^{\mathrm{T}}$. The $16 \mathrm{~S}$ rRNA gene sequence similarity

Table 1. Characteristics that differentiate species belonging to the genus Methylobacter

Strains/species: 1, Methylobacter tundripaludum SV96 ${ }^{\mathrm{T}}$; 2, Methylobacter psychrophilus Z-0021 ${ }^{\mathrm{T}}$ (data from Omelchenko et al., 1996); 3, Methylobacter luteus (four strains); 4, Methylobacter marinus (three strains); 5, Methylobacter whittenburyi (six strains) (data in columns 3-5 from Bowman et al., 1993, 1995). +, $91-100 \%$ of strains are positive;,$- 0-10 \%$ of strains are positive; $\mathrm{d}, 21-81 \%$ of strains are positive; (?), uncertain (strain is lost and result cannot be confirmed); ND, not determined. All strains have type I membranes and utilize the RuMP pathway.

\begin{tabular}{|c|c|c|c|c|c|}
\hline Characteristic & 1 & 2 & 3 & 4 & 5 \\
\hline \multicolumn{6}{|l|}{ Cell morphology } \\
\hline Cocci & - & + & + & + & + \\
\hline Ellipsoidal & - & - & $\mathrm{d}$ & + & + \\
\hline Rods & + & - & - & - & - \\
\hline Coccobacilli & - & - & - & + & $\mathrm{d}$ \\
\hline Cyst formation & - & $-(?)$ & + & + & + \\
\hline Motility & - & - & - & + & + \\
\hline Pigmentation ${ }^{\star}$ & $\mathrm{P}$ & W/B & $\mathrm{Y}$ & $\mathrm{DB}$ & DB \\
\hline Optimum growth temperature $\left({ }^{\circ} \mathrm{C}\right)$ & 23 & $3 \cdot 5-10$ & 30 & 37 & 30 \\
\hline $\mathrm{NaCl}$ requirement & - & - & - & + & - \\
\hline Oxidase & + & ND & + & + & + \\
\hline Urease & - & ND & + & - & - \\
\hline nifH gene & + & ND & + & + & - \\
\hline $\mathrm{G}+\mathrm{C}$ content $(\mathrm{mol} \%)$ & 47 & $45 \cdot 6$ & $49-51$ & $54-55$ & $49-54$ \\
\hline Major PLFA(s) & $16: 1 \omega 8,16: 1 \omega 7$ & $16: 1$ & $16: 1 \omega 7 c$ & $16: 1 \omega 7 c$ & $16: 1 \omega 7 c$ \\
\hline
\end{tabular}

${ }^{\star}$ DB, Diffusible brown; P, pink; W/B, white or buff; Y, yellow. 


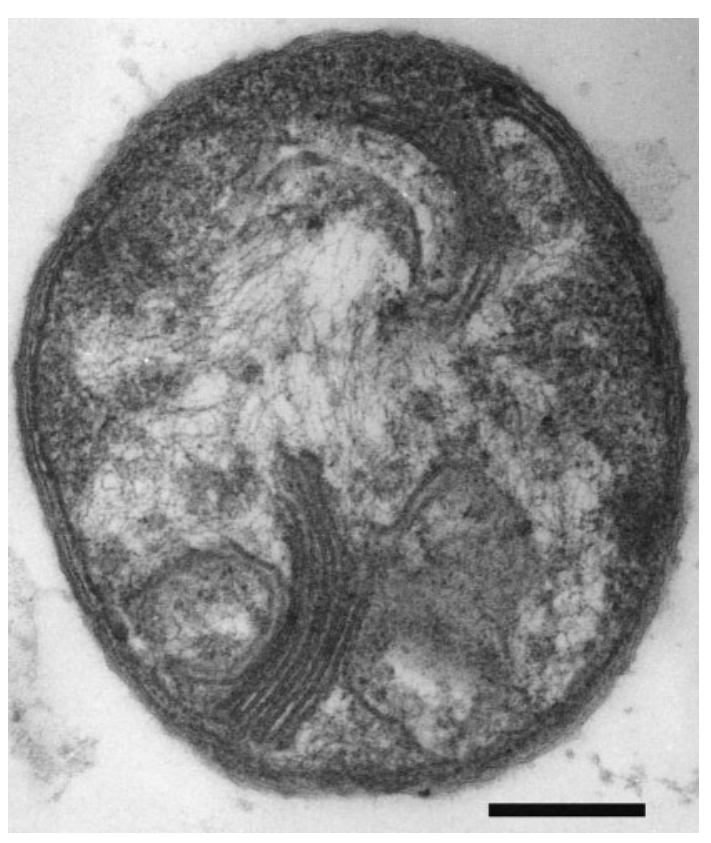

Fig. 3. Transmission electron micrograph of a cell of Methylobacter tundripaludum SV96 ${ }^{\top}$. Bar, $200 \mathrm{~nm}$.

between $\mathrm{SV} 96^{\mathrm{T}}$ and the second most closely related bacterium, Methylobacter luteus ATCC $49878^{\mathrm{T}}$, was $97 \%$. DNADNA hybridization demonstrated a relatedness value of $10 \%$ between SV96 $^{\mathrm{T}}$ and Methylobacter luteus ATCC $49878^{\mathrm{T}}$. The differences between Methylobacter luteus ATCC $49878^{\mathrm{T}}$, Methylobacter psychrophilus Z-0021 ${ }^{\mathrm{T}}$, Methylobacter marinus $\mathrm{A}^{\mathrm{T}}{ }^{\mathrm{T}}$, Methylobacter whittenburyi ATCC $51738^{\mathrm{T}}$ and $\mathrm{SV} 96^{\mathrm{T}}$ are described in Table 1. Because of the genotypic and phenotypic differences between $\mathrm{SV} 96^{\mathrm{T}}$ and the

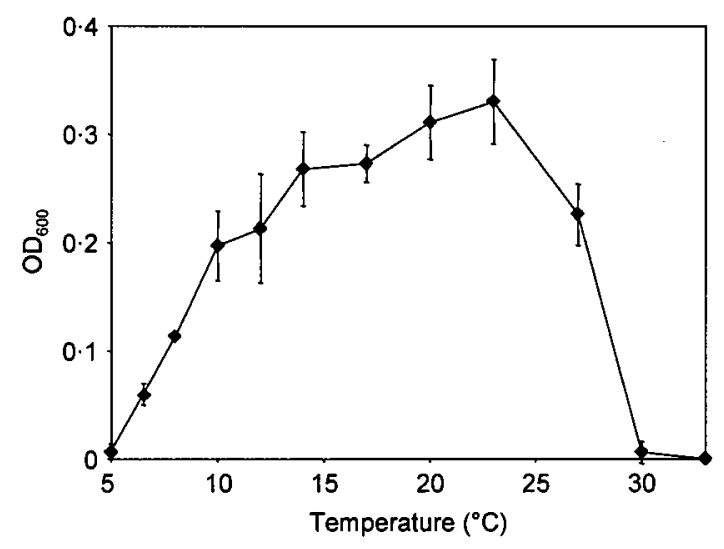

Fig. 4. Growth of Methylobacter tundripaludum $\mathrm{SV} 6^{\top}$ at temperatures ranging from 5 to $40^{\circ} \mathrm{C}$. Data points represent mean values for net growth, calculated by subtracting the $\mathrm{OD}_{600}$ of the starting culture from the $\mathrm{OD}_{600}$ of the 5-day-old cultures. Error bars represent standard deviations of three replicates at each temperature. other Methylobacter species (including 16S rRNA gene sequence and DNA-DNA hybridization), we propose the name Methylobacter tundripaludum sp. nov. for strain SV $96^{\mathrm{T}}$.

\section{Description of Methylobacter tundripaludum sp. nov.}

Methylobacter tundripaludum (tun.dri.pa'lu.dum. N.L. n. tundra treeless polar region with permanently frozen subsoil; L. n. palus -udis marsh; N.L. gen. pl. n. tundripaludum of the tundra marshes).

Gram-negative, straight, fat, rod-shaped cells. Cells are $0 \cdot 8-1 \cdot 3 \mu \mathrm{m}$ in diameter and $1 \cdot 9-2 \cdot 5 \mu \mathrm{m}$ long. Cells are pale-pink pigmented, occur singly, in pairs or in long chains, and are non-motile. Grows on methane as sole carbon and energy source; shows poor to no growth on methanol. Possesses a type I intracytoplasmic membrane system. Assimilates carbon via the ribulose monophosphate (RuMP) pathway and does not possess sMMO. Cells are catalase- and oxidase-positive. Possesses a nifH gene. Optimal growth occurs at $23{ }^{\circ} \mathrm{C}$, but grows well down to $10^{\circ} \mathrm{C}$; no growth occurs above $30^{\circ} \mathrm{C}$. Does not require $\mathrm{NaCl}$ for growth and cells are lysed by $2 \%$ SDS. Grows well from pH $5 \cdot 5$ to $7 \cdot 9$. Major PLFAs are 16:1 $1 \omega 8(34 \cdot 9 \%), 16: 1 \omega 7(23 \cdot 4 \%)$ and $16: 1 \omega 5 t(26 \cdot 3 \%)$. The DNA G $+\mathrm{C}$ content is $47 \mathrm{~mol} \%$. Methylobacter tundripaludum strain $\mathrm{SV}^{\mathrm{T}} 6^{\mathrm{T}}$ shows $10 \%$ DNA-DNA hybridization with Methylobacter luteus ATCC $49878^{\mathrm{T}}$.

The type strain is $\mathrm{SV}^{\mathrm{T}}{ }^{\mathrm{T}}\left(=\mathrm{ATCC}\right.$ BAA $-1195^{\mathrm{T}}=\mathrm{DSM}$ $\left.17260^{\mathrm{T}}\right)$, isolated from an Arctic wetland soil near $\mathrm{Ny}-$ Ålesund, Svalbard.

\section{Acknowledgements}

We thank Frida Lise Daae (Institute of Biology, University of Bergen, Norway) for determination of $\mathrm{G}+\mathrm{C}$ content and Espen Hansen (Department of Biology, University of Tromsø, Norway) for the fatty acid analyses, the Norwegian Research Council for financial support (grant 121458/720), the Norwegian Polar Institute for economic support of fieldwork and UNIS (the University Courses on Svalbard) for access to laboratory facilities. We also thank Professor Peter Kämpfer for helpful discussion.

\section{References}

Bowman, J. P., Sly, L. I., Nichols, P. D. \& Hayward, A. C. (1993). Revised taxonomy of the methanotrophs: description of Methylobacter gen. nov., emendation of Methylococcus, validation of Methylosinus and Methylocystis species, and a proposal that the family Methylococcaceae includes only the group I methanotrophs. Int J Syst Bacteriol 43, 735-753.

Bowman, J. P., Sly, L. I. \& Stackebrandt, E. (1995). The phylogenetic position of the family Methylococcaceae. Int J Syst Bacteriol 45, 182-185.

Brusseau, G. A., Tsien, H. C., Hanson, R. S. \& Wackett, L. P. (1990). Optimization of trichloroethylene oxidation by methanotrophs and 
the use of a colorimetric assay to detect soluble methane monooxygenase activity. Biodegradation 1, 19-29.

Ezaki, T., Hashimoto, T. \& Yabuuchi, E. (1989). Fluorometric deoxyribonucleic acid-deoxyribonucleic acid hybridization in microdilution wells as an alternative to membrane filter hybridization in which radioisotopes are used to determine genetic relatedness among bacterial strains. Int J Syst Bacteriol 39, 224-229.

Felsenstein, J. (1993). PHYLIP - Phylogenetic Interference Package, version 3.5c. Distributed by the author. Department of Genome Sciences, University of Washington, Seattle, USA.

Fuse, H., Ohta, M., Takimura, O., Murakami, K., Inoue, H., Yamaoka, Y., Oclarit, J. M. \& Omori, T. (1998). Oxidation of trichloroethylene and dimethyl sulfide by a marine Methylomicrobium strain containing soluble methane monooxygenase. Biosci Biotechnol Biochem 62, 1925-1931.

Graham, D. W., Korich, D. G., LeBlanc, R. P., Sinclair, N. A. \& Arnold, R. G. (1992). Applications of a colorimetric plate assay for soluble methane monooxygenase activity. Appl Environ Microbiol 58, 2231-2236.

Høj, L., Olsen, R. A. \& Torsvik, V. L. (2005). Archaeal communities in High Arctic wetlands at Spitsbergen, Norway $\left(78^{\circ} \mathrm{N}\right)$ as characterized by $16 \mathrm{~S}$ rRNA gene fingerprinting. FEMS Microbiol Ecol 53, 89-101.

Lane, D. J. (1991). 16S/23S rRNA sequencing. In Nucleic Acid Techniques in Bacterial Systematics, pp. 115-175. Edited by E. Stackebrandt \& M. Goodfellow. Chichester: Wiley.

Lidstrom, M. E. (1988). Isolation and characterization of marine methanotrophs. Antonie van Leeuwenhoek 54, 189-199.

Ludwig, W., Strunk, O., Westram, R. \& 29 other authors (2004). ARB: a software environment for sequence data. Nucleic Acids Res 32, 1363-1371.

Mandel, M., Igambi, L., Bergendahl, J., Dobson, M. L., Jr \& Scheltgen, E. (1970). Correlation of melting temperature and cesium chloride buoyant density of bacterial deoxyribonucleic acid. J Bacteriol 101, 333-338.
McDonald, I. R. \& Murrell, J. C. (1997). The particulate methane monooxygenase gene $p m o A$ and its use as a functional gene probe for methanotrophs. FEMS Microbiol Lett 156, 205-210.

Miguez, C. B., Bourque, D., Sealy, J. A., Greer, C. W. \& Groleau, D. (1997). Detection and isolation of methanotrophic bacteria possessing soluble methane monooxygenase (sMMO) genes using the polymerase chain reaction (PCR). Microb Ecol 33, 21-31.

Omelchenko, M. V., Vasilyeva, L. V. \& Zavarzin, G. A. (1993). Psychrophilic methanotroph from Tundra soil. Curr Microbiol 27, 255-259.

Omelchenko, M. V., Vasilyeva, L. V., Zavarzin, G. A., Savel'eva, N. D., Lysenko, A. M., Mityushina, L. L., Khmelenina, V. N. \& Trotsenko, Y. A. (1996). A novel psychrophilic methanotroph of the genus Methylobacter. Mikrobiologiia 65, 339-343 (in Russian).

Page, R. D. M. (1996). TreeView: an application to display phylogenetic trees on personal computers. Comput Appl Biosci 12, 357-358.

Poly, F., Monrozier, L. J. \& Bally, R. (2001). Improvement in the RFLP procedure for studying the diversity of nifH genes in communities of nitrogen fixers in soil. Res Microbiol 152, 95-103.

Romanovskaya, V. A., Malashenko, Yu. R. \& Bogachenko, V. N. (1978). Corrected diagnoses of genera and species of methaneassimilating bacteria. Mikrobiologiia 47, 120-130 (in Russian).

Thompson, J. D., Gibson, T. J., Plewniak, F., Jeanmougin, F. \& Higgins, D. G. (1997). The CLUSTAL_X windows interface: flexible strategies for multiple sequence alignment aided by quality analysis tools. Nucleic Acids Res 25, 4876-4882.

Tourova, T. P., Omel'chenko, M. V., Fegeding, K. V. \& Vasil'eva, L. V. (1999). The phylogenetic position of Methylobacter psychrophilus sp. nov. Mikrobiologiia 68, 493-497 (in Russian).

Vela, G. R. \& Wyss, O. (1964). Improved stain for visualization of Azotobacter encystment. J Bacteriol 87, 476-477.

Whittenbury, R., Phillips, K. C. \& Wilkinson, J. F. (1970). Enrichment, isolation and some properties of methane-utilizing bacteria. J Gen Microbiol 61, 205-218. 